\title{
What is the frequency of anatomical variations and pathological findings in maxillary sinuses among patients subjected to maxillofacial cone beam computed tomography? A systematic review
}

\author{
Javier Ata-Ali ${ }^{1,2}$, Jose-Vicente Diago-Vilalta ${ }^{2}$, María Melo ${ }^{2}$, Leticia Bagán ${ }^{2}$, Maria-Costanza Soldini ${ }^{2}$, Chiara \\ Di-Nardo ${ }^{2}$, Fadi Ata-Ali ${ }^{2}$, José-Félix Mañes-Ferrer ${ }^{2}$
}

${ }^{1}$ Public Dental Health Service. Arnau de Vilanova Hospital, Valencia, Spain

${ }^{2}$ Department of Dentistry, European University of Valencia, Valencia, Spain

Correspondence:

Public Dental Health Service.

Arnau de Vilanova Hospital

San Clemente Street 12

46015-Valencia (Spain)

javiataali@hotmail.com

\author{
Ata-Ali J, Diago-Vilalta JV, Melo M, Bagán L, Soldini MC, Di-Nardo C, \\ Ata-Ali F, Mañes-Ferrer JF. What is the frequency of anatomical varia- \\ tions and pathological findings in maxillary sinuses among patients sub- \\ jected to maxillofacial cone beam computed tomography? A systematic \\ review. Med Oral Patol Oral Cir Bucal. 2017 Jul 1;22 (4):e400-9. \\ http://www.medicinaoral.com/medoralfree01/v22i4/medoralv22i4p400.pdf

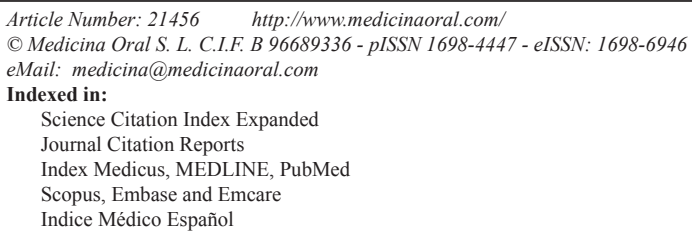

Received: 05/06/2016 Accepted: 03/05/2017

\begin{abstract}
Background: When considering dental implant rehabilitation in atrophic posterior sectors, the maxillary sinuses must be evaluated in detail. Knowledge of the anatomical variations and of the potential lesions found in these structures conditions the outcome of sinus lift procedures and therefore of the dental implants. A systematic review is made to determine the frequency of anatomical variations and pathological findings in maxillary sinuses among patients subjected to cone beam computed tomography (CBCT).

Material and Methods: A PubMed (MEDLINE) literature search was made of articles published up until 20 December 2015. The systematic review was conducted based on the Preferred Reporting Items for Systematic Reviews and Meta-analysis (PRISMA). The quality of the studies included in the review was assessed using the Methodological Index for Nonrandomized Studies (MINORS).

Results: The combinations of search terms resulted in a list of 3482 titles. Twenty-three studies finally met the inclusion criteria and were entered in the systematic review, comprising a total of 11,971 patients. The most common anatomical variations were pneumatization and sinus septa. The prevalence of maxillary sinus disease ranged from $7.5 \%$ to $66 \%$. The most common pathological findings of the maxillary sinus were mucosal thickening, sinusitis and sinus opacification.

Conclusions: Although the main indication of CBCT of the maxillary sinus in dentistry is sinus floor elevation/ treatment planning and evaluation prior to dental implant placement, this imaging modality is increasingly also used for endodontic and periodontal purposes. There is no consensus regarding the cutoff point beyond which mu-
\end{abstract}


cosal thickening of the maxillary sinus should be regarded as pathological, and the definition of maxillary sinusitis moreover varies greatly in the scientific literature. In this regard, international consensus is required in relation to these concepts, with a clear distinction between healthy and diseased maxillary sinuses.

Key words: Maxillary sinus, cone beam computed tomography, dental implant, maxillary sinus floor augmentation, sinus membrane, sinus floor elevation.

\section{Introduction}

Implant placement in the posterior maxilla may be a challenging surgical procedure because of the reduced vertical bone height resulting from expansion of the maxillary sinus. Sinus floor elevation procedures are often needed to treat such bone deficiencies, in order to allow correct placement of dental implants (1). Apart from differences in indications, transcrestal and lateral window sinus augmentation procedures are predictable, and implants placed in grafted sinuses have high survival rates (2-4). Nevertheless, complications still occur, associated mainly with membrane perforation that is often caused by inadequate surgical planning or maneuvers (5). In this regard, perforation or damage of the Schneiderian membrane reportedly occurs in an average of $19.5 \%$ of the cases (up to $58.3 \%$ ) (2).

The anatomical variability that may be found in the maxillary sinus has a strong impact upon the risk of sinus membrane perforation and subsequent implant failure. Computed tomography is considered the gold standard for sinus diagnosis, because of its ability to provide multiple sections through the sinus at different planes and allow visualization of bone and soft tissues (6). Barone et $a l$. noted that membrane perforation might lead to graft migration and sinus infection. Thus, an intact Schneiderian membrane is desirable to ensure better vascularization, graft stability and environmental conditions for maturation of the inserted bone graft materials $(7,8)$.

When considering dental implant rehabilitation in atrophic posterior sectors, the maxillary sinuses must be evaluated in detail. Knowledge of the anatomical variations and of the potential lesions found in these structures conditions the outcome of sinus lift procedures and therefore of the dental implants. Since the maxillary sinus is an anatomical structure that can be visualized by maxillary CBCT, the professionals performing such explorations must not only record the radiological findings for which CBCT is requested (dental implants, endodontics, periodontics, etc.) but should also evaluate the rest of the structures seen during the exploration. In this regard, the aim of the present systematic review was to answer the question: What is the frequency of anatomical variations and pathological findings in maxillary sinuses among patients subjected to maxillofacial cone beam computed tomography (CBCT)?

\section{Material and Methods}

The Preferred Reporting Items for Systematic Reviews and Meta-analysis (PRISMA) statement was used in this study (9).

- PICO question

What is the frequency of anatomical variations and pathological findings in maxillary sinuses among patients subjected to maxillofacial cone beam computed tomography (CBCT)?

- Search Strategy for the Identification of Studies

The PubMed (MEDLINE) database of the United States National Library of Medicine was used for a literature search of articles published up until December 2015. The following search terms were used in different combinations: "cone beam computed tomography", "mucosal thickness", "sinus membrane" "maxillary sinus", "CBCT", "posterior maxilla". Two examiners read the titles and abstracts of all studies, and no blinding was carried out regarding author names, journals or publication date. The search was completed with a review of the references of the selected articles in order to identify additional studies not found in the initial literature search. In addition, a manual search (likewise up until December 2015) was made of the following journals: Clinical Implant Dentistry and Related Research, Clinical Oral Investigations, Clinical Oral Implants Research, Implant Dentistry, The International Journal of Oral and Maxillofacial Implants, Journal of Clinical Periodontology, Journal of Oral Implantology, Journal of Periodontology and Medicina Oral, Patología Oral y Cirugía Bucal.

-Study Selection Criteria

Before starting the study, a series of inclusion and exclusion criteria were established. Chosen full-text articles were assessed for the following inclusion criteria: randomized clinical trials, prospective cohort studies, controlled clinical trials and retrospective studies, with a sample size of $\geq 200$ patients.

We excluded studies involving patients with congenital diseases (e.g., harelip and cleft palate) or maxillofacial traumatisms that could affect the region of the maxillary sinus. In vitro studies, animal studies, systematic reviews and case reports were also excluded. Authors were contacted for clarification of missing information when necessary. No restrictions were placed on the year 
or language of publication. All articles selected from the electronic and manual searches were independently assessed by the first and second authors of the present study, according to the established inclusion criteria. Any disagreements between the reviewing authors were resolved by consensus, or by consulting the last signing author of the study. The level of agreement between the two reviewing authors was assessed using the Cohen kappa statistic.

- Data Extraction and Assessment of Methodological Quality

Data were independently extracted from the included studies by two reviewers (JAA and JVDV). A third reviewer (JFMF) was consulted in the event of any disagreement.

Two authors independently evaluated the quality of the studies included in the systematic review using the Methodological Index for Nonrandomized Studies (MINORS) (10). The MINORS scale includes the following points: (a) a clearly stated aim; (b) inclusion of consecutive patients; (c) prospective collection of data; (d) appropriate endpoints; (e) unbiased assessment; (f) a follow-up period; (g) losses to follow-up of $<5 \%$; and (h) prospective calculation of the study size. The items on the MINORS scale are scored as 0 (not reported), 1 (reported but inadequate) or 2 (reported and adequate). We defined study quality as poor $(<5)$, fair $(6-10)$ or good $(>11)$. The level of agreement between the two reviewing authors was assessed using the Cohen kappa statistic.

\section{Results}

- Study selection

The combinations of search terms resulted in a list of 3482 titles. Of these, 1412 were found to be duplicated; as a result, 2070 references were reviewed. Subsequently, 2005 papers were excluded on the basis of the evaluation of the title and abstract, thus leaving 65 articles for eligibility assessment. Twenty-three publications finally met the inclusion criteria and were thus selected for inclusion in the systematic review (Fig. 1). The main indication of maxillary sinus CBCT was sinus floor elevation/ treatment planning and evaluation prior to dental implant placement $(50 \%)$, followed by exploration for endodontic and periodontal purposes. In only two articles was CBCT indicated for orthodontic evaluation. Inter-rater reliability based on the kappa statistic was 0.89 .

- Assessment of study quality

Two reviewers independently and in duplicate evaluated the quality of the included studies (Table 1) as part of the data extraction process. Any disagreements were resolved by consensus or by consulting the last signing author of the present study. The mean score for the global studies was 10 (range 7-12). Of the 23 studies finally included, $11(11,13,15,17,21-26,28)$ were of fair quality, with a score of 6-10 points, and 12 studies $(1,12,14,16,18-20,27,29-32)$ were of good quality, with a score of $\geq 11$ points. Agreement between the reviewers for risk of bias assessment as evidenced by the kappa statistic was 0.90 .

- Description of the studies

One cross-sectional study and 22 retrospective studies were included in the systematic review. The demographic data (patient age and sex) and information referred to the maxillary sinus findings of the publications are summarized in table 2. In the present systematic review we included a total of 11,971 patients.

- Anatomical variations of the healthy maxillary sinus Over $50 \%$ of the included studies $(n=15 ; 65.2 \%)$ identified anatomical variations of the healthy sinus.

- Sinus septa

Five studies $(1,12,9,22,24)$ offered information on the prevalence of maxillary sinus septa, which ranged from $33.2-58 \%$. Most patients (12) with septa showed one septum in one sinus (24.6\%); $13.7 \%$ showed one septum in each sinus. Other combinations (up to three septa per sinus) were found in $8.7 \%$ of the patients. The septa were commonly found in the region of the first and second molars (60.7\%) (1).

- Relationship between the roots of maxillary teeth and the maxillary sinus floor

Several studies $(26,30,31)$ offered data on the relationship between the roots of maxillary tooth and the maxillary sinus floor. In one publication (26) involving 5166 maxillary premolars and molars, the roots extended below the sinus floor mainly in relation to the first (92.4\%) and second premolars (71.6\%); the roots penetrated into the sinus floor in $34.2 \%$ of the cases, and contacted the sinus floor in $36.7 \%$ of the cases.

- Other anatomical variations

In one study (19) involving 500 patients, the most frequent anatomical variation detected was pneumatization (83.2\%). This same study (19) described the presence of exostosis in $2.6 \%$ of the cases, with unilateral location in $84.6 \%$ of the cases. Three publications $(15,19,21)$ offered information on the prevalence of maxillary sinus hypoplasia, which ranged from $0.2-4.8 \%$.

- Maxillary sinus disease

- Thickening of the sinus membrane

The prevalence of mucosal thickening ranged between $35.1-66 \%(13,20,21,25,28,32)$. The cutoff point beyond which thickening is considered pathological is normally 1-3 mm. However, the prevalence of maxillary sinus mucosal thickening was $41.5 \%$ in patients without apical periodontitis, over $70 \%$ in patients with mild and moderate apical periodontitis, and $100 \%$ in those with severe apical periodontitis (17).

- Sinusitis and mucosal cysts

The prevalence of maxillary sinusitis ranged from 7.5$50 \%(11,13,20)$. The prevalence of mucosal cysts in turn ranged from $3.5-16.4 \%(11,16,18,32)$.

- Opacification of the maxillary sinus 


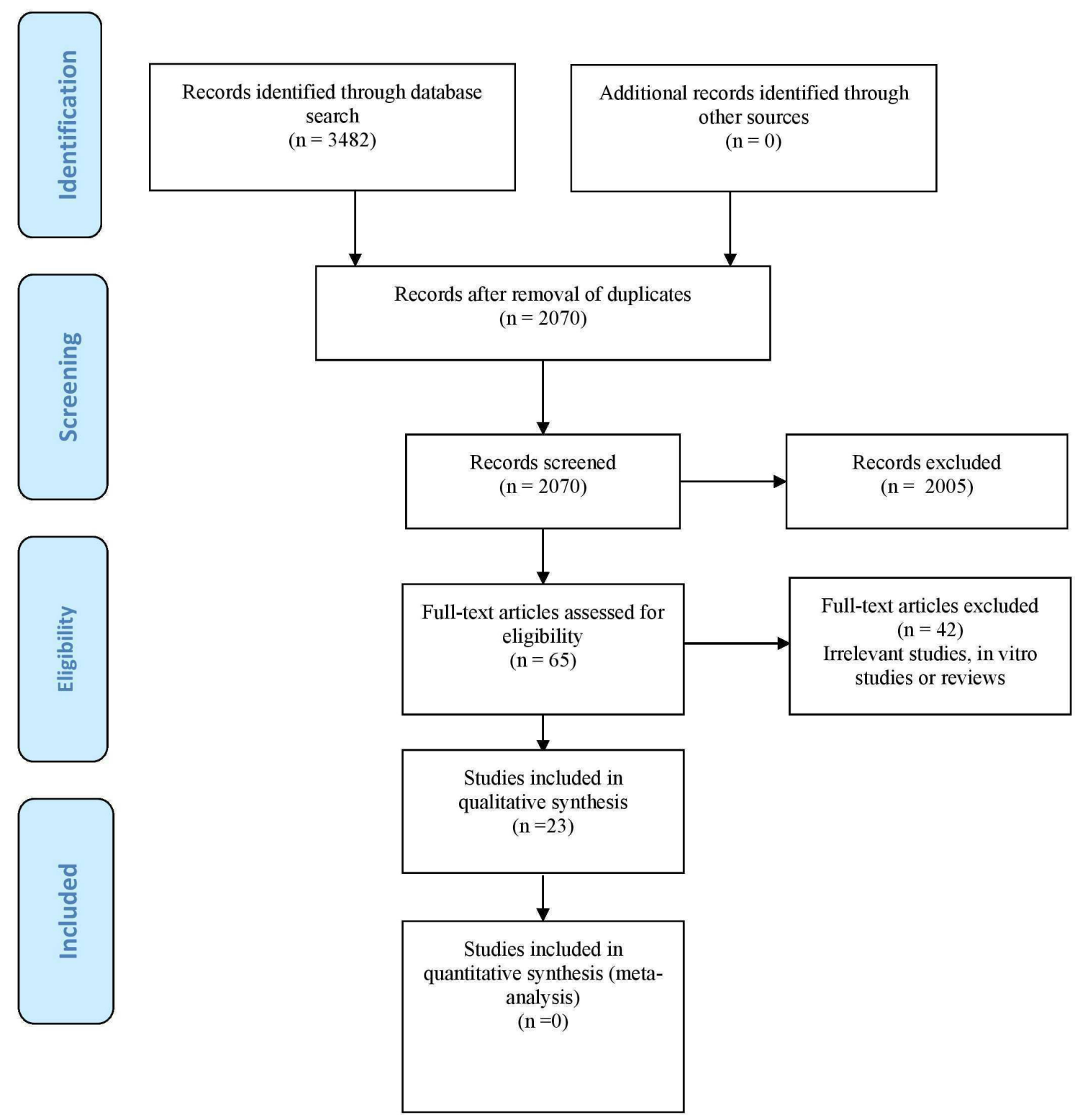

Fig. 1. Prisma ${ }^{\circledR}$ flow chart of the search processes and results.

Partial or complete opacification showed a prevalence of $1.8-68.2 \%(14,16,19,21,28,32)$. In one study (16) involving 1026 maxillary sinuses, $68.2 \%$ presented opacification of less than one-third of the sinus.

- Antroliths and polyps

The prevalence of antroliths ranged from $1 \%$ (32) to $3.2 \%(19,21)$, while the frequency of polyps ranged from $2.3 \%$ (11) to $25 \%$ (32).

- Other lesions of the maxillary sinus

One publication (21) on the frequency distribution of sinus abnormalities in images from 703 patients and 1406 sinuses documented malignant tumors in $1 \%$ of the cases, benign odontogenic tumors in $0.3 \%$, fibrous dysplasia in $0.2 \%$, and ossifying fibroma in $0.2 \%$. Another study (19) reported a foreign body prevalence of $1.6 \%$.

\section{Discussion}

The present systematic review has examined the scientific evidence with a view to determining the frequency of anatomical variations and pathological findings of the maxillary sinuses in patients subjected to maxillofacial CBCT. Twenty-three publications were included in our systematic review, comprising a total of 11,971 patients. The most common anatomical variations were pneumatization and sinus septa. The prevalence of sinus maxillary disease ranged from $7.5-66 \%$ - the most common disorders being mucosal thickening, sinusitis and opacification.

Maxillary sinus septa are barriers of cortical bone that divide the maxillary sinus floor into multiple compartments known as recesses (33). Septa have become in- 
creasingly important after the introduction of sinus floor augmentation surgery, since their presence may complicate both creation and inversion of the access window in the lateral sinus wall, as well as elevation of the sinus membrane from the bony sinus floor (34). Septa with a low height (up to $2 \mathrm{~mm}$ ) do not require further treatment (12), because in routine cases the membrane can be elevated without further procedures. The shapes of the instruments determine the need to remove parts of the septa to release the sinus mucosa from the bone. Medium-size septa require resection, because the palatal area of the sinus cavity cannot be reached by the instruments. High septa in turn lead to partial or complete separation of the sinus cavity, requiring the preparation of two or even three cavities. The orientation of septa limits the mobility of the sinus instruments, resulting in a need for increased vestibular access for complicationfree handling without creating uncontrolled pressure on

\begin{tabular}{|c|c|c|c|c|c|c|c|c|c|c|c|c|c|c|c|c|c|c|c|c|c|c|c|}
\hline 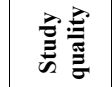 & 竎 & $\begin{array}{l}\overrightarrow{0} \\
\stackrel{0}{0}\end{array}$ & 憙 & O' & 离 & $\begin{array}{l}\overrightarrow{8} \\
\dot{0}\end{array}$ & 䓌 & $\begin{array}{l}: \overrightarrow{0} \\
\stackrel{0}{0}\end{array}$ & $\begin{array}{l}\overline{8} \\
\stackrel{0}{0}\end{array}$ & $\begin{array}{l}\text { రัo } \\
\stackrel{0}{0}\end{array}$ & 䄰 & \begin{tabular}{|l|} 
竧 \\
\end{tabular} & 䓌 & 弪 & 镸 & 言 & $\begin{array}{l}\overrightarrow{0} \\
0 \\
0\end{array}$ & 言 & $\mid \begin{array}{l}\vec{z} \\
0 \\
0\end{array}$ & $\begin{array}{l}\overrightarrow{0} \\
\stackrel{0}{0}\end{array}$ & $\mid \begin{array}{l}\overrightarrow{0} \\
8 \\
0\end{array}$ & $\begin{array}{l}\overrightarrow{0} \\
\dot{0}\end{array}$ & $\begin{array}{l}: \\
\circ \\
0\end{array}$ \\
\hline 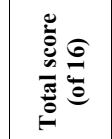 & $\infty$ & $=$ & $r$ & $=$ & $\infty$ & $=$ & $a$ & $=$ & $=$ & $\simeq$ & $\Theta$ & $\infty$ & $\infty$ & $a$ & $\Theta$ & $\varrho$ & $\simeq$ & $\infty$ & $=$ & $=$ & $=$ & $\simeq$ & $\approx$ \\
\hline 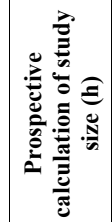 & - & $\sim$ & - & $N$ & - & - & - & $\sim$ & - & $\sim$ & - & - & - & - & - & $\sim$ & $\sim$ & - & $N$ & $\alpha$ & $N$ & $N$ & a \\
\hline 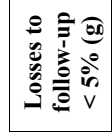 & - & $\sim$ & - & $\sim$ & - & $\sim$ & - & - & $\sim$ & $N$ & - & - & - & - & - & - & $\sim$ & - & - & - & $N$ & $N$ & $a$ \\
\hline 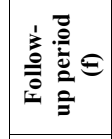 & 0 & 0 & 0 & 0 & 0 & 0 & 0 & 0 & 0 & 0 & 0 & 0 & 0 & 0 & 0 & 0 & 0 & 0 & 0 & 0 & 0 & 0 & 0 \\
\hline 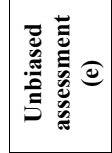 & 0 & 0 & 0 & 0 & 0 & 0 & 0 & 0 & 0 & 0 & 0 & 0 & 0 & 0 & 0 & 0 & 0 & 0 & 0 & 0 & 0 & 0 & 0 \\
\hline 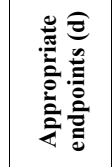 & $\sim$ & $\sim$ & - & $N$ & $N$ & $N$ & - & $\sim$ & $N$ & $\alpha$ & $\sim$ & $N$ & $\sim$ & $\sim$ & $N$ & $\sim$ & $\sim$ & $\sim$ & $N$ & $\alpha$ & - & $N$ & 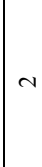 \\
\hline 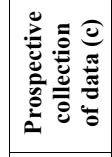 & - & - & - & - & - & $\sim$ & $N$ & $\sim$ & $\sim$ & $N$ & $\sim$ & - & - & $\alpha$ & 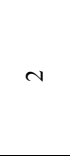 & $\sim$ & $\sim$ & - & $N$ & $\sim$ & $N$ & $N$ & $a$ \\
\hline 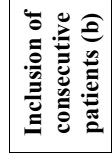 & - & $\sim$ & - & $N$ & - & $N$ & $N$ & $\sim$ & $\sim$ & N & $\sim$ & - & - & - & $\alpha$ & - & $\sim$ & - & $N$ & $\sim$ & $N$ & $\alpha$ & N \\
\hline 离 & $\sim$ & $\sim$ & $\sim$ & $N$ & $N$ & $\sim$ & $N$ & $\sim$ & $N$ & $\sim$ & $\alpha$ & 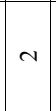 & $\sim$ & $\alpha$ & $N$ & $N$ & $\sim$ & $N$ & 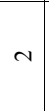 & $\sim$ & $\alpha$ & $\sim$ & a \\
\hline 竞 & 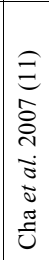 & 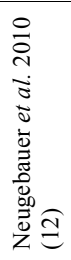 & 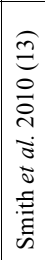 & 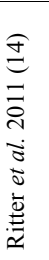 & 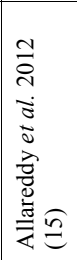 & 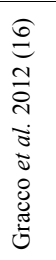 & 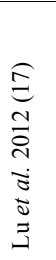 & 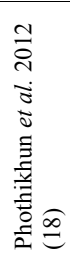 & 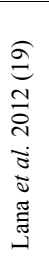 & 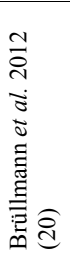 & 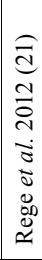 & 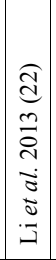 & 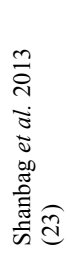 & 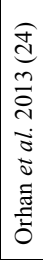 & 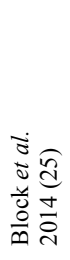 & 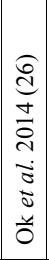 & 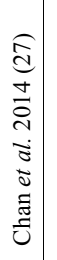 & 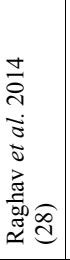 & 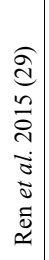 & 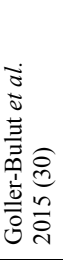 & 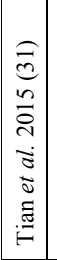 & 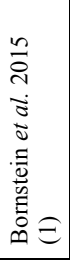 & 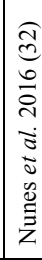 \\
\hline
\end{tabular}


Table 2. Demographic data and information referred to the findings of the maxillary sinus.

\begin{tabular}{|c|c|c|}
\hline Author & Type of study / sample & Cone beam computed tomography (CBCT) findings of the maxillary sinus \\
\hline Cha et al. 2007 (11) & $\begin{array}{l}\text { Retrospective } \\
\text { Patients: } 252 ; 100 \mathrm{M}, 152 \mathrm{~F} \text {. } \\
\text { Mean age: } 18.6 \text { years }\end{array}$ & $\begin{array}{l}\text { Sinusitis } 7.5 \% \text {, retention cysts } 3.5 \% \text {, polyps } 2.3 \% \text {, deviation of the nasal septum } 0.4 \% \text {, large } \\
\text { turbinate } 0.4 \%\end{array}$ \\
\hline $\begin{array}{l}\text { Smith et al. } \\
2010(13)\end{array}$ & $\begin{array}{l}\text { Retrospective } \\
\text { Patients: } 883 ; 386 \mathrm{M}, 497 \mathrm{~F} . \\
\text { Mean age: } 44.2 \text { years }\end{array}$ & $\begin{array}{l}\text { A total of } 50.0 \% \text { of the patients had evidence of maxillary sinusitis. There was a statistically } \\
\text { significant higher prevalence of maxillary sinusitis in males }(61.8 \%) \text { compared to females } \\
(41.8 \% ; \mathrm{p}<0.0001) .12 .1 \% \text { had right maxillary sinusitis, } 15.6 \% \text { had left-side involvement, and } \\
21.0 \% \text { had bilateral sinus disease. }\end{array}$ \\
\hline Neugebauer et al. $2010(12)$ & $\begin{array}{l}\text { Retrospective } \\
\text { Patients: } 1029 ; 536 \mathrm{M}, 493 \mathrm{~F} . \\
\text { Mean age: } 40.9 \text { years }\end{array}$ & $\begin{array}{l}\text { Of the } 1029 \text { patients investigated, } 545(53 \%) \text { showed no septum and } 484(47 \%) \text { showed at least } \\
\text { one septum in one sinus. In terms of position, } 257 \text { septa were close to the first molar, } 225 \text { were } \\
\text { near the second molar, } 144 \text { were close to the third molar, and } 139 \text { were near the second } \\
\text { premolar. Forty-four septa were associated with the first premolar. In the area of the canines, } \\
\text { only } 5 \text { septa were detected. }\end{array}$ \\
\hline Ritter et al. 2011 (14) & $\begin{array}{l}\text { Retrospective } \\
\text { Patients: } 1029 ; 536 \mathrm{M} \text { and } 493 \\
\text { F } \\
\text { Mean age: } 44.1 \text { years }\end{array}$ & $\begin{array}{l}\text { Pathological findings in either one or both sinuses were recorded in } 579 \text { patients }(56.3 \%) .280 \\
(27.2 \%) \text { showed pathological signs in both sinuses, and } 299 \text { patients }(29.1 \%) \text { in either one of } \\
\text { their sinuses. Patients } \geq 60 \text { years old in this study showed the most pathological signs, and there } \\
\text { was a statistically significant difference between the investigated age groups (p=0.02). Mucosal } \\
\text { thickening } 38.1 \% \text {; total opacification } 7 \% \text {; partial opacification with liquid accumulation } 12 \% \text {; } \\
\text { polypoidal mucosal thickening } 6.5 \% \text {. }\end{array}$ \\
\hline Allareddy et al. 2012 (15) & $\begin{array}{l}\text { Retrospective } \\
\text { Patients: } 1000 ; 382 \text { F } 618 \text { F. } \\
\text { Age: } 5-87 \text { years }\end{array}$ & $\begin{array}{l}\text { Mucositis / sinusitis / mucus retention pseudocysts (grouped as a single category) were the most } \\
\text { common findings }(55.1 \%) \text {. Hypoplastic sinuses has a prevalence of } 2.1 \% \text { and osteoma } 0.4 \% \text {. }\end{array}$ \\
\hline Gracco et al. 2012 (16) & $\begin{array}{l}\text { Retrospective } \\
\text { Patients: } 513 ; 382 \mathrm{M}, 618 \mathrm{~F} \\
\text { Age: } 12-60 \text { years }\end{array}$ & $\begin{array}{l}\text { A total of } 50.3 \% \text { of the patients and } 30.9 \% \text { of the sinuses had pathological alterations, with } \\
38.8 \% \text { and } 11.5 \% \text { of the subjects showing bilateral and unilateral incidental findings, } \\
\text { respectively. } \\
\text { Mucosal thickening ( }>1 \mathrm{~mm} \text { ) was observed in } 40.1 \% \text { of the patients and } 25.1 \% \text { of the sinuses. } \\
\text { Pseudocysts were detected in } 10.1 \% \text { of the patients and } 5.75 \% \text { of the sinuses; } 68.2 \% \text { of the } \\
\text { sinuses presented less than one-third opacification. }\end{array}$ \\
\hline Lu et al. 2012 (17) & $\begin{array}{l}\text { Retrospective } \\
\text { Patients: } 372 ; 178 \mathrm{M}, 194 \mathrm{~F} . \\
\text { Mean age: } 35.8 \text { years }\end{array}$ & $\begin{array}{l}\text { Among the patients with maxillary posterior teeth apical periodontitis, more than } 80 \% \text { had } \\
\text { maxillary sinus mucosal thickening, and the prevalence of maxillary sinus mucosal thickening } \\
\text { increased with the size of the lesion. The prevalence of maxillary sinus mucosal thickening was } \\
41.5 \% \text { in patients without apical periodontitis, }>70 \% \text { in patients with mild and moderate apical } \\
\text { periodontitis, and } 100 \% \text { in those with severe apical periodontitis. }\end{array}$ \\
\hline Phothikhun et al. 2012 (18) & $\begin{array}{l}\text { Retrospective } \\
\text { Patients: } 250 ; 110 \mathrm{M}, 140 \mathrm{~F} \\
\text { Mean age: } 46.1 \text { years }\end{array}$ & $\begin{array}{l}\text { The average mucosal thickness in sinuses with mucosal thickening was } 5.0-3.9 \mathrm{~mm} \text { (range: } \\
1.6-20.3 \mathrm{~mm} \text { ). Distribution of mucosal thickness of sinuses with mucosal thickening: } 65.8 \% \text { : } \\
1.1-5 \mathrm{~mm} ; 25.3 \%: 5.1-10 \mathrm{~mm} ; 4.8 \%: 10.1-15 \mathrm{~mm} ; 4.1 \%>15 \mathrm{~mm} \text {. } \\
\text { Cysts: } 16.4 \% \text { of the patients and } 10 \% \text { of the sinuses. Mean height: } 14.4 \pm 6.4 \mathrm{~mm} \text {. } \\
\text { Sinuses with severe periodontal bone loss were three times more likely to present mucosal } \\
\text { thickening, whereas periapical lesions and root canal fillings showed no such association. }\end{array}$ \\
\hline Lana et al. 2012 (19) & $\begin{array}{l}\text { Cross-sectional } \\
\text { Patients: } 500 ; 238 \mathrm{M}, 262 \mathrm{~F} \\
\text { Mean age: } 52 \text { years }\end{array}$ & $\begin{array}{l}\text { The anatomical variations detected comprised pneumatization }(83.2 \%) \text {, antral septa }(44.4 \%) \text {, } \\
\text { hypoplasia }(4.8 \%) \text { and exostosis }(2.6 \%) \\
\text { The identified lesions were mucosal thickening ( } \leq 3 \mathrm{~mm} \text { in } 54.8 \% \text { and }>3 \mathrm{~mm} \text { in } 62.6 \%) \text {, } \\
\text { polypoid lesions }(21.4 \%) \text {, discontinuity of the sinus floor }(17.4 \%) \text {, air-fluid level }(4.4 \%) \text {, bone } \\
\text { thickening of the maxillary sinus wall }(3.8 \%) \text { and antroliths }(3.2 \%) \text {. Discontinuity of the sinus } \\
\text { lateral wall was identified in } 2.6 \% \text { of the patients. Sinus opacification and foreign body were } \\
\text { respectively found in only } 1.8 \% \text { and } 1.6 \% \text { of the patients. Pneumatization sites were multiple in } \\
46 \% \text {. In } 54 \% \text { of the cases, pneumatization was located only at a single site (alveolar). }\end{array}$ \\
\hline Brüllmann et al. $2012(20)$ & $\begin{array}{l}\text { Retrospective } \\
\text { Patients: } 204 ; 83 \mathrm{M}, 121 \mathrm{~F} \\
\text { Mean age: } 47.5 \text { years }\end{array}$ & $\begin{array}{l}\text { A total of } 74 \% \text { of the patients showed mucosal findings. Thirty-three percent of the patients } \\
\text { showed findings of apical transparency, } 12 \% \text { had perforations of the vestibular wall, } 11 \% \text { had } \\
\text { perforations of the maxillary sinus floor, and } 0.5 \% \text { had a perforation of the palatal wall. Overall, } \\
56 \% \text { of the patients showed basal mucosal thickening }(>3 \mathrm{~mm}) \text {. Undiagnosed hyperplasia of } \\
\text { the sinus mucosa may contribute to the clinical symptoms, leading to a diagnosis of atypical } \\
\text { odontalgia or temporomandibular pain. }\end{array}$ \\
\hline Rege et al. $2012(21)$ & $\begin{array}{l}\text { Retrospective } \\
\text { Patients: } 1113 ; 435 \mathrm{M}, 678 \mathrm{~F} \text {. } \\
\text { Mean age: } 49 \text { years }\end{array}$ & $\begin{array}{l}\text { Inflammatory lesions: membrane thickness }>3 \mathrm{~mm}: 66 \% \text {; retention cysts: } 10.1 \% \text {; opacification: } \\
7.8 \% \text {; polyps: } 5.6 \% \text {; antroliths: } 3.2 \% \text {. } \\
\text { Rest of sinus lesions: orosinusal communication: } 2.2 \% \text {; fractures: } 1.4 \% \text {; malignancy: } 1 \% \text {; } \\
\text { inflammatory cyst: } 0.4 \% \text {; odontogenic cyst: } 0.3 \% \text {; benign odontogenic tumors: } 0.3 \% \text {; sinus } \\
\text { hypoplasia: } 0.2 \% \text {; fibrous dysplasia: } 0.2 \% \text {; ossifying fibroma: } 0.2 \% \text {. }\end{array}$ \\
\hline Shanbag et al. 2013 (23) & $\begin{array}{l}\text { Retrospective } \\
\text { Patients: } 243 ; 131 \mathrm{M} 112 \mathrm{~F} \\
\text { Mean age: } 50.9 \text { years }\end{array}$ & $\begin{array}{l}\text { On analyzing the maxillary sinuses: sinus mucosal thickness }<2 \mathrm{~mm}: 55.4 \% ; 2-5 \mathrm{~mm}: 24.7 \% \text {; } \\
5-10 \mathrm{~mm}: 10.8 \% ;>10 \mathrm{~mm}: 9.1 \% \text {. } \\
\text { A total of } 2.5 \% \text { sinuses showed signs of acute sinusitis. } \\
\text { Teeth with periapical lesions were most frequently first and second molars. Mucosal thickening } \\
>2 \mathrm{~mm} \text { was more frequently observed in relation to teeth with periapical lesions and } \\
\text { periodontal disease }(\mathrm{p}<0.001) \text { and was mostly } \leq 5 \mathrm{~mm}(\mathrm{p}<0.001) \text {. } \\
\text { Sinus mucosal thickening was highly prevalent }(60 \%) \text { in this sample of dental patients and } \\
\text { twice as more frequent in males than in females. } \\
\text { Teeth with periapical lesions were } 9.75 \text { times more likely to be associated to mucosal }\end{array}$ \\
\hline
\end{tabular}


Table 2 continue. Demographic data and information referred to the findings of the maxillary sinus.

\begin{tabular}{|c|c|c|}
\hline Orhan et al. 2013 (24) & $\begin{array}{l}\text { Retrospective } \\
\text { Patients: } 272 ; 120 \mathrm{M} \text { and } 152 \mathrm{~F} \\
\text { Mean age: } 6-83 \text { years }\end{array}$ & $\begin{array}{l}\text { The prevalence of maxillary sinus segments with septa was } 58 \% \text {. } \\
\text { Maxillary sinus septa were higher in partially edentulous patients than in edentate and } \\
\text { completely edentulous subjects }(\mathrm{p}<0.05) \text {. Analysis of the anatomical location of the septa } \\
\text { within the sinus revealed that } 12.2 \% \text { septa were located in the anterior region, } 69.1 \% \text { in the } \\
\text { middle region and } 18.6 \% \text { in the posterior region. All detected septa showed a mediolateral } \\
\text { orientation. }\end{array}$ \\
\hline Li et al. 2013 (22) & $\begin{array}{l}\text { Retrospective } \\
\text { Patients: } 424\end{array}$ & $\begin{array}{l}\text { Patients with septa: } 44.81 \% \text {; sinuses with septa: } 32.67 \% \text {. } \\
\text { A total of } 21.2 \% \text { of the patients had multiple septa; } 20.5 \% \text { of the patients had bilateral septa. } \\
\text { Most frequent location: central zone of the sinus }(59.94 \%) \text {. } \\
\text { Mean septal height: } 5.5-5.9 \mathrm{~mm} \text {. Mean septal length: } 7.8-8.1 \mathrm{~mm} \text {. }\end{array}$ \\
\hline Block et al. 2014 (25) & $\begin{array}{l}\text { Retrospective } \\
\text { Patients: } 831 \\
\text { Mean age: } 52.2 \text { years }\end{array}$ & $\begin{array}{l}\text { A total of } 1662 \text { sinuses were evaluated, with thickening of at least one sinus membrane in } \\
46.7 \% \text { and } 30.1 \% \text { of all sinuses evaluated. The prevalence of patients and sinuses with sinus } \\
\text { membrane thickening was } 36.8 \% \text { of the patients and } 24.3 \% \text { of the sinuses }(2-5 \mathrm{~mm}), 6.0 \% \text { of } \\
\text { the patients and } 3.7 \% \text { of the sinuses }(>5 \mathrm{~mm} \text { to the level of the ostium), and } 3.6 \% \text { of the } \\
\text { patients and } 2.2 \% \text { of the sinuses (sinus with soft tissue material beyond the ostium). Unilateral } \\
\text { sinus disease was more common than bilateral disease. After tooth removal, sinus membrane } \\
\text { thickening decreased, but did not completely resolve proportional to the severity of sinus } \\
\text { obliteration before tooth removal. }\end{array}$ \\
\hline Ok et al. 2014 (26) & $\begin{array}{l}\text { Retrospective } \\
\text { Patients: } 849 ; 428 \mathrm{M} \text { and } 421 \mathrm{~F} \\
\text { Mean age: } 14.8 \text { years }\end{array}$ & $\begin{array}{l}\text { Roots extending below the sinus floor was most frequently seen in the first }(92.4 \%) \text { and second } \\
\text { premolars }(71.6 \%) \text {. In addition, it occurred most frequently in the mesiobuccal }(39.9 \%) \text { and } \\
\text { distobuccal }(39.7 \%) \text { roots of the first molar teeth. } \\
\text { Roots penetrating into the sinus floor: } 34.2 \% \text { (most frequently palatine roots of the first molar } \\
\text { teeth). Roots contacting the sinus floor: } 36.7 \% \text { (most frequently in the mesiobuccal } \\
\text { roots of the second molar teeth). The relationship between the posterior teeth and the sinus floor } \\
\text { differed according to the age decade interval }(\mathrm{p}<0.05) \text {. The second decade and males were } \\
\text { most susceptible to undesirable results. }\end{array}$ \\
\hline Chan et al. 2014 (27) & $\begin{array}{l}\text { Retrospective } \\
\text { Patients: } 320 ; 135 \mathrm{M}, 185 \mathrm{~F} \\
\text { Mean age: } 50.1 \text { years }\end{array}$ & $\begin{array}{l}\text { The mean sinus width at the usual lower boundary of lateral window osteotomy (average } 2.3 \\
\text { mm from the floor of sinus) was } 9.0(2.8) \mathrm{mm} \text {, with the thirty-third and sixty-seventh percentile } \\
\text { sinus width values being } 7.6 \text { and } 9.9 \mathrm{~mm} \text {, respectively. The mean sinus width at the usual upper } \\
\text { boundary of lateral window osteotomy ( } 15 \mathrm{~mm} \text { from crest) was } 16.0(4.4) \mathrm{mm} \text {, with the thirty- } \\
\text { third and sixty-seventh percentile sinus width values being } 14.0 \text { and } 17.3 \mathrm{~mm} \text {, respectively. }\end{array}$ \\
\hline Raghav et al. 2014 (28) & $\begin{array}{l}\text { Retrospective } \\
\text { Patients: } 201 ; 110 \mathrm{M} 91 \mathrm{~F} \\
\text { Mean age: } 32 \text { years }\end{array}$ & $\begin{array}{l}\text { The prevalence for the sum of incidental findings was } 59.7 \% \text {. Maxillary sinus scans showed } \\
\text { mucosal thickening in } 35.1 \% \text {, opacification in } 16.6 \% \text {, polypoidal-mucosal thickening in } 7.2 \% \text {, } \\
\text { others in } 0.7 \% \text {, and no findings in } 40.2 \% \text {. Of } 110 \text { male patients, } 79 \% \text { had at least some } \\
\text { pathology in either of the sinuses, whereas } 72.5 \% \text { of the } 91 \text { investigated scans of female } \\
\text { patients showed pathological signs in either sinus. }\end{array}$ \\
\hline Ren et al. 2015 (29) & $\begin{array}{l}\text { Retrospective } \\
\text { Patients: } 221 ; 113 \mathrm{M} \text { and } 108 \mathrm{~F} \\
\text { Mean age: } 30.1 \text { years }\end{array}$ & $\begin{array}{l}\text { The prevalence of mucosal thickening paralleled the degree of alveolar bone loss, with } 87.9 \% \\
\text { of patients displaying mucosal thickening when alveolar bone loss of the maxillary posterior } \\
\text { teeth was severe. Similarly, the periodontal status of patients was worse with mucosal } \\
\text { thickening than with normal mucosa. Furcation lesions and vertical infrabony pockets were } \\
\text { more likely to be associated to mucosal thickening. }\end{array}$ \\
\hline Goller-Bulut et al. 2015 (30) & $\begin{array}{l}\text { Retrospective } \\
\text { Patients: } 205 ; 101 \mathrm{M}, 104 \mathrm{~F} \\
\text { Mean age: } 38.8 \text { years }\end{array}$ & $\begin{array}{l}\text { There was a significant correlation between mucosal thickening of maxillary sinus and both } \\
\text { periodontal bone loss and age. The frequency of mucosal thickening increased as the severity of } \\
\text { the apical lesion increased. A positive correlation was found between mucosal thickening and } \\
\text { the degree of periodontal bone loss and periapical lesions. Teeth with inadequate root canal } \\
\text { therapy and extensive caries were associated with mucosal thickening; pulp-periapical } \\
\text { alterations were significantly related to mucosal thickening. }\end{array}$ \\
\hline Tian et al. $2015(31)$ & $\begin{array}{l}\text { Retrospective } \\
\text { Patients: } 848 ; 302 \text { M } 546 \text { F } \\
\text { Mean age: } 34 \text { years }\end{array}$ & $\begin{array}{l}\text { The first premolar was always farther and the second molar mesiobuccal root was closer to the } \\
\text { border of the maxillary sinus floor. The root protruding into the sinus was rare in the first } \\
\text { premolar and dominated in the first molar palatine root. The root was closer to the border of the } \\
\text { maxillary sinus floor before the age of } 20 \text { and farther after the age of } 60 \text {. Age significantly } \\
\text { influenced the mean distances and the frequency of the root above the maxillary sinus floor. }\end{array}$ \\
\hline Bornstein et al. 2016 (1) & $\begin{array}{l}\text { Retrospective } \\
\text { Patients: } 212 ; 86 \mathrm{M}, 126 \mathrm{~F} \\
\text { Mean age: } 53.8 \text { years }\end{array}$ & $\begin{array}{l}\text { In most cases, septa were observed in the first or second molar region on the floor of the } \\
\text { maxillary sinus. Of the septa identified, } 33.1 \% \text { were located in the roof of the sinus, whereas } \\
24.3 \% \text { were related to the infraorbital canal. The most common orientation of the septa was } \\
\text { coronal }(61.8 \%) \text {, followed by axial }(7.6 \%) \text { and sagittal }(3.6 \%) \text {. There was no evidence that the } \\
\text { frequency of maxillary sinus septa is associated to age, sex, or dentition status of the patients. }\end{array}$ \\
\hline Nunes et al. 2016 (32) & $\begin{array}{l}\text { Retrospective } \\
\text { Patients: } 200 ; 85 \mathrm{M} \text { and } 125 \mathrm{~F} \\
\text { Mean age: } 41.2 \text { years }\end{array}$ & $\begin{array}{l}\text { Most sinus abnormalities were associated to at least one maxillary posterior tooth with } \\
\text { a periapical lesion }(\mathrm{p}>0.05) \text {. The most frequent sinus abnormality in the presence of a } \\
\text { periapical lesion was mucosal thickening. The highest frequency of abnormalities was found } \\
\text { when the radiolucent area was subjacent to the sinus floor. } \\
\text { Mucosal thickening } 38 \% \text {, sinus polyp } 25 \% \text {, antral pseudocyst } 5.4 \% \text {, nonspecific opacification } \\
1.08 \% \text {, periostitis } 5.4 \% \text {, antrolith } 1 \% \text {, mucosal thickening and periostitis } 13 \% \text {, mucosal } \\
\text { thickening and antrolith } 2.1 \% \text {, mucosal thickening, periostitis, and antrolith } 1 \% \text {, sinus polyp } \\
\text { and antral pseudocyst } 1 \% \text {, sinus polyp and periostitis } 4.3 \% \text {, antral pseudocyst and periostitis } \\
1 \% \text {, periostitis and antrolith } 1 \% \text {. }\end{array}$ \\
\hline
\end{tabular}

$\mathrm{F}=$ females $; \mathrm{M}=$ males 
the membrane (35). In our systematic review, the prevalence of maxillary sinus septa ranged from $33.2-58 \%$. There is no consensus regarding the cutoff point beyond which mucosal thickening of the maxillary sinus is considered pathological. In this regard, different authors define pathological thickening as $\geq 1 \mathrm{~mm}(16)$, $\geq$ $2 \mathrm{~mm}(17)$ or $>3 \mathrm{~mm}(19,21)$. In a study involving 831 patients, the prevalence of sinus membrane thickening was $36.8 \%(2-5 \mathrm{~mm})$ of the patients and $24.3 \%$ of the sinuses; $6.0 \%$ of the patients and $3.7 \%$ of the sinuses presented more than $5 \mathrm{~mm}$ to the level of the ostium, and $3.6 \%$ of the patients and $2.2 \%$ of the sinuses presented soft tissue material beyond the ostium (25). A study (18) of CBCT images of 500 maxillary sinuses found the average mucosal thickness in sinuses with mucosal thickening to be 5.0-3.9 $\mathrm{mm}$ (range 1.6-20.3 mm). The majority of sinuses with mucosal thickening had a mucosal thickness of $<5 \mathrm{~mm}$. Severe periodontal bone loss was significantly associated to mucosal thickening of the maxillary sinus. Sinuses with severe periodontal bone loss were three times more likely to have mucosal thickening (18), while Brüllman et al. recorded an odds ratio (OR) of 10.2 for the association of periodontitis to visibly thickened mucosa (20).

The most common causes of odontogenic sinusitis are dental abscesses and periodontal disease perforating the Schneiderian membrane. It is estimated that $10-12 \%$ of all cases of maxillary sinusitis have a dental origin (18). Sinusitis is the leading cause of mucosal thickening in symptomatic individuals (18). The relationship between dental infections and maxillary sinusitis is well established (36). The cause of mucosal thickening among asymptomatic individuals, however, remains unclear. In a study (37) of 190 patients treated for unilateral paranasal sinusitis, odontogenic infection was implicated in approximately $70 \%$ of the cases of unilateral paranasal sinusitis. Odontogenic maxillary sinusitis can be difficult to diagnose, and imaging exploration under various conditions is recommended. The definition of maxillary sinusitis varies greatly in the scientific literature. This is reflected by the findings of our systematic review, where the prevalence of maxillary sinusitis ranged widely from $7.5-50 \%(11,13,20)$. According to some authors such as Smith et al. (13), sinusitis is defined as any evident thickening of the mucosa in the maxillary sinus, with a prevalence of $50.0 \%$ in a series of 883 patients. Iatrogenic perforation of the maxillary sinus membrane during membrane elevation increases the chance of postoperative sinusitis, owing to bacterial graft contamination or graft migration into the sinus cavity (38). With appropriate treatment, intraoperative sinus membrane perforations did not represent an elevated risk for implant loss, infectious complications or displacement of graft material (39). In a study comprising 407 sinus grafts in 300 patients (39), the prevalence of Schneide- rian membrane perforation was $8.6 \%$, and was significantly correlated to the presence of sinus septa $(\mathrm{OR}=$ 4.8), smoking $(\mathrm{OR}=4.8)$ and decreased residual bone height $(\mathrm{OR}=0.01)$. The frequency of postoperative sinusitis was significantly greater for sinus membrane perforation $(\mathrm{OR}=10.5)$ and in smokers $(\mathrm{OR}=12.3)$.

Panoramic radiography has been used as a routine screening tool for evaluation of the maxillomandibular complex (40). However, panoramic radiography has limitations in diagnosing sinus disorders, and computed tomography remains the most effective diagnostic technique (41). Martínez-González et al. (41) compared panoramic radiography and computed tomography in evaluating 84 maxillary sinuses, and found panoramic radiography to have limitations in diagnosing changes in the maxillary sinus, whereas computed tomography seemed to be a better imaging tool. In a study published by Wolff et al. (42) in a total of 253 patients subjected to both panoramic radiographic and $\mathrm{CBCT}$ analysis, CBCT imaging provided significantly more surgically relevant information in cases of implant dentistry and maxillary sinus diagnosis. Visualization quality of the maxillary sinus and bony structures in CBCT appears to be similar to that afforded by computed tomography. However, CBCT generates high-resolution isotropic volume data and therefore could offer benefits in evaluating the bony aspects of the maxillary sinus thanks to the use of a lower radiation dose (14).

- Limitations

The results of our systematic review cannot be extrapolated to the general population, since the great majority of the patients in the included studies corresponded to CBCT explorations performed in the context of dental implant planning, i.e., the patients were typically elderly individuals with missing teeth in the upper maxilla. The main limitation of our systematic review is the fact that the results were not integrated in a quantitative analysis, thereby precluding the conduction of a meta-analysis. This was mainly due to significant heterogeneity between publications referred to disease definitions (with multiple definitions regarding mucosal thickening and sinusitis of the maxillary sinus), measured outcomes and other aspects. Another aspect that also must be taken into account on interpreting the results is the fact that 12 studies were of good quality, while 11 were of fair quality - the mean MINORS score being 10 out of 16 (range 7-12). We were not able to take the "comparator" component $\mathrm{C}$ of the PICO question into account. In some cases the PICO question cannot be applied in its entirety, particularly in the case of anatomical studies. Huang et al. (43) reported that in some cases it is difficult to encode certain question classes without modifying the existing PICO structure or introducing counterintuitive elements. The PICO representation is unable to capture anatomical relations that may be relevant in 
a clinical question. There is no slot in the PICO framework capable of capturing "body parts".

\section{Conclusions}

Although the main indication of maxillary sinus CBCT is sinus floor elevation/treatment planning and evaluation prior to dental implant placement, this imaging modality is increasingly also used for endodontic and periodontal purposes. There is no consensus regarding the cutoff point beyond which mucosal thickening of the maxillary sinus should be regarded as pathological, and the definition of maxillary sinusitis moreover varies greatly in the scientific literature. In this regard, international consensus is required in relation to these concepts, with a clear distinction between healthy and diseased maxillary sinuses in order to facilitate comparisons between studies.

\section{References}

1. Bornstein MM, Seiffert C, Maestre-Ferrín L, Fodich I, Jacobs R, Buser D, et al. An Analysis of Frequency, Morphology, and Locations of Maxillary Sinus Septa Using Cone Beam Computed Tomography. Int J Oral Maxillofac Implants. 2016;31:280-7.

2. Pjetursson BE, Tan WC, Zwahlen M, Lang NP. A systematic review of the success of sinus floor elevation and survival of implants inserted in combination with sinus floor elevation. J Clin Periodontol. 2008;35:216-40.

3. Pjetursson BE, Rast C, Brägger U, Schmidlin K, Zwahlen M, Lang NP. Maxillary sinus floor elevation using the (transalveolar) osteotome technique with or without grafting material. Part I: Implant survival and patients' perception. Clin Oral Implants Res. 2009;20:66776.

4. Tan WC, Lang NP, Zwahlen M, Pjetursson BE. A systematic review of the success of sinus floor elevation and survival of implants inserted in combination with sinus floor elevation. Part II: transalveolar technique. J Clin Periodontol. 2008;35:241-54.

5. von Arx T, Fodich I, Bornstein MM, Jensen SS. Perforation of the sinus membrane during sinus floor elevation: a retrospective study of frequency and possible risk factors. Int J Oral Maxillofac Implants. 2014;29:718-26.

6. Mafee MF, Tran BH, Chapa AR. Imaging of rhinosinusitis and its complications: Plain film, CT, and MRI. Clin Rev Allergy Immunol 2006;30:165-186.

7. Barone A, Santini S, Marconcini S, Giacomelli L, Gherlone E, Covani U. Osteotomy and membrane elevation during the maxillary sinus augmentation procedure. A comparative study: piezoelectric device vs. conventional rotative instruments. Clin Oral Implants Res. 2008;19:511-5.

8. Pikos MA. Maxillary sinus membrane repair: report of a technique for large perforations. Implant Dent. 1999;8:29-34.

9. Moher D, Liberati A, Tetzlaff J, Altman DG; PRISMA Group. Preferred reporting items for systematic reviews and meta-analyses: the PRISMA statement. Ann Intern Med. 2009;151:264-9, W64.

10. Slim K, Nini E, Forestier D, Kwiatkowski F, Panis Y, Chipponi J. Methodological index for non-randomized studies (MINORS): development and validation of a new instrument. ANZ J Surg. 2003;73:712-6.

11. Cha JY, Mah J, Sinclair P. Incidental findings in the maxillofacial area with 3-dimensional cone-beam imaging. Am J Orthod Dentofacial Orthop. 2007;132:7-14.

12. Neugebauer J, Ritter L, Mischkowski RA, Dreiseidler T, Scherer $\mathrm{P}$, Ketterle M, et al. Evaluation of maxillary sinus anatomy by conebeam CT prior to sinus floor elevation. Int J Oral Maxillofac Implants. 2010;25:258-65.
13. Smith KD, Edwards PC, Saini TS, Norton NS. The prevalence of concha bullosa and nasal septal deviation and their relationship to maxillary sinusitis by volumetric tomography. Int J Dent. 2010;2010. pii: 404982.

14. Ritter L, Lutz J, Neugebauer J, Scheer M, Dreiseidler T, Zinser MJ, et al. Prevalence of pathologic findings in the maxillary sinus in cone-beam computerized tomography. Oral Surg Oral Med Oral Pathol Oral Radiol Endod. 2011;111:634-40.

15. Allareddy V, Vincent SD, Hellstein JW, Qian F, Smoker WR, Ruprecht A. Incidental findings on cone beam computed tomography images. Int J Dent. 2012;2012:871532.

16. Gracco A, Incerti Parenti S, Ioele C, Alessandri Bonetti G, Stellini E. Prevalence of incidental maxillary sinus findings in Italian orthodontic patients: a retrospective cone-beam computed tomography study. Korean J Orthod. 2012;42:329-34.

17. Lu Y, Liu Z, Zhang L, Zhou X, Zheng Q, Duan X, et al. Associations between maxillary sinus mucosal thickening and apical periodontitis using cone-beam computed tomography scanning: a retrospective study. J Endod. 2012;38:1069-74.

18. Phothikhun S, Suphanantachat S, Chuenchompoonut V, Nisapakultorn K. Cone-beam computed tomographic evidence of the association between periodontal bone loss and mucosal thickening of the maxillary sinus. J Periodontol. 2012;83:557-64.

19. Lana JP, Carneiro PM, Machado Vde C, de Souza PE, Manzi FR, Horta MC. Anatomic variations and lesions of the maxillary sinus detected in cone beam computed tomography for dental implants. Clin Oral Implants Res. 2012;23:1398-403.

20. Brüllmann DD, Schmidtmann I, Hornstein S, Schulze RK. Correlation of cone beam computed tomography (CBCT) findings in the maxillary sinus with dental diagnoses: a retrospective cross-sectional study. Clin Oral Investig. 2012;16:1023-9.

21. Rege IC, Sousa TO, Leles CR, Mendonça EF. Occurrence of maxillary sinus abnormalities detected by cone beam CT in asymptomatic patients. BMC Oral Health. 2012;12:30.

22. Li J, Zhou ZX, Yuan ZY, Yuan H, Sun C, Chen N. [An anatomical study of maxillary sinus septum of Han population in Jiangsu region using cone-beam CT]. Shanghai Kou Qiang Yi Xue. 2013;22:52-7.

23. Shanbhag S, Karnik P, Shirke P, Shanbhag V. Association between periapical lesions and maxillary sinus mucosal thickening: a retrospective cone-beam computed tomographic study. J Endod. 2013;39:853-7.

24. Orhan K, Kusakci Seker B, Aksoy S, Bayindir H, Berberoğlu A, Seker E. Cone beam CT evaluation of maxillary sinus septa prevalence, height, location and morphology in children and an adult population. Med Princ Pract. 2013;22:47-53.

25. Block MS, Dastoury K. Prevalence of sinus membrane thickening and association with unhealthy teeth: a retrospective review of 831 consecutive patients with 1,662 cone-beam scans. J Oral Maxillofac Surg. 2014;72:2454-60.

26. Ok E, Güngör E, Colak M, Altunsoy M, Nur BG, Ağlarci OS. Evaluation of the relationship between the maxillary posterior teeth and the sinus floor using cone-beam computed tomography. Surg Radiol Anat. 2014;36:907-14.

27. Chan HL, Suarez F, Monje A, Benavides E, Wang HL. Evaluation of maxillary sinus width on cone-beam computed tomography for sinus augmentation and new sinus classification based on sinus width. Clin Oral Implants Res. 2014;25:647-52.

28. Raghav M, Karjodkar FR, Sontakke S, Sansare K. Prevalence of incidental maxillary sinus pathologies in dental patients on cone-beam computed tomographic images. Contemp Clin Dent. 2014;5:361-5.

29. Ren S, Zhao H, Liu J, Wang Q, Pan Y. Significance of maxillary sinus mucosal thickening in patients with periodontal disease. Int Dent J. 2015;65:303-10.

30. Goller-Bulut D, Sekerci AE, Köse E, Sisman Y. Cone beam computed tomographic analysis of maxillary premolars and molars to detect the relationship between periapical and marginal bone loss and mucosal thickness of maxillary sinus. Med Oral Patol Oral Cir Bucal. 2015;20:e572-9. 
31. Tian XM, Qian L, Xin XZ, Wei B, Gong Y. An Analysis of the Proximity of Maxillary Posterior Teeth to the Maxillary Sinus Using Cone-beam Computed Tomography. J Endod. 2016;42:371-7.

32. Nunes CA, Guedes OA, Alencar AH, Peters OA, Estrela CR, Estrela C. Evaluation of Periapical Lesions and Their Association with Maxillary Sinus Abnormalities on Cone-beam Computed Tomographic Images. J Endod. 2016;42:42-6.

33. Pommer B, Ulm C, Lorenzoni M, Palmer R, Watzek G, Zechner W. Prevalence, location and morphology of maxillary sinus septa: systematic review and meta-analysis. J Clin Periodontol. 2012;39:769-73.

34. Betts NJ, Miloro M. Modification of the sinus lift procedure for septa in the maxillary antrum. J Oral Maxillofac Surg. 1994;52:332-3.

35. Katranji A, Fotek P, Wang HL. Sinus augmentation complications: Etiology and treatment. Implant Dent. 2008;17:339-349.

36. Brook I. Sinusitis. Periodontol 2000. 2009;49:126-139

37. Matsumoto Y, Ikeda T, Yokoi H, Kohno N. Association between odontogenic infections and unilateral sinus opacification. Auris Nasus Larynx. 2015;42:288-93.

38. Schwarz L, Schiebel V, Hof M, Ulm C, Watzek G, Pommer B. Risk Factors of Membrane Perforation and Postoperative Complications in Sinus Floor Elevation Surgery: Review of 407 Augmentation Procedures. J Oral Maxillofac Surg. 2015;73:1275-82.

39. Becker ST, Terheyden H, Steinriede A, Behrens E, Springer I, Wiltfang J. Prospective observation of 41 perforations of the Schneiderian membrane during sinus floor elevation. Clin Oral Implants Res. 2008;19:1285-9.

40. Donizeth-Rodrigues C, Fonseca-Da Silveira M, Gonçalves-De Alencar AH, Garcia-Santos-Silva MA, Francisco-De-Mendonça E, Estrela C. Three-dimensional images contribute to the diagnosis of mucous retention cyst in maxillary sinus. Med Oral Patol Oral Cir Bucal. 2013;18:e151-7.

41. Martínez-González JM, Barona-Dorado C, Arias-Irimia O, Martínez-Rodríguez N, Fernández-Domínguez M. Panoramic and tomographic implant studies: role in the diagnosis of sinus disorders. Med Oral Patol Oral Cir Bucal. 2010;15:e611-5.

42. Wolff C, Mücke T, Wagenpfeil S, Kanatas A, Bissinger O, Deppe H. Do CBCT scans alter surgical treatment plans? Comparison of preoperative surgical diagnosis using panoramic versus cone-beam CT images. J Craniomaxillofac Surg. 2016;44:1700-1705.

43. Huang X, Lin J, Demner-Fushman D. Evaluation of PICO as a knowledge representation for clinical questions. AMIA Annu Symp Proc. 2006:359-63.

\section{Funding}

None.

\section{Acknowledgments}

The authors gratefully acknowledge the help of Ms. Maria Jesus Baeza (librarian of Arnau de Vilanova Hospital, Valencia, Spain).

\section{Conflicts of interest}

The authors declare that they have no conflicts of interest. 